Jurnal Magisma Vol. 6 No. 1 - Tahun 2018 | 35

\title{
PENGARUH KEPEMIMPINAN, LINGKUNGAN KERJA NON FISIK, KOMPENSASI DAN MOTIVASI KERJA TERHADAP KINERJA PEGAWAI PUSKESMAS KEDUNGBANTENG KABUPATEN TEGAL
}

\author{
Henifah \\ Universitas Diponegoro \\ henifahskm@yahoo.co.id
}

\begin{abstract}
ABSTRAK
Puskesmas Kedungbanteng adalah salah satu Puskesmas di Kabupaten Tegal, berdasarkan dari laporan tahunan Dinas Kesehatan Kabupaten Tegal Puskesmas Kedungbanteng pada tahun 2016 cakupan hasil kinerja puskesmas sebesar 92,1\% atau menurun dibandingkan dengan tahun 2015 sebasar 93,85\%. Indeks Kepuasan Pasien (IKP) Puskesmas Kedungbanteng tahun 2016 yaitu sebesar $77,45 \%$. Tujuan penelitian ini memperoleh bukti empiris mengenai pengaruh kepemimpinan, lingkungan kerja non fisik, kompensasi dan motivasi kerja terhadap kinerja Pegawai Puskesmas Kedungbanteng Kabupaten Tegal.

Populasi dari penelitian ini adalah seluruh Pegawai di Puskesmas Kedungbanteng Kabupaten Tegal yang berjumlah 48 orang, sampel penelitian adalah menggunakan total sampling yaitu pada semua populasi yang berjumlah 48 responden. Pengumpulan data menggunakan kuesioner, teknik analisis data menggunakan regresi linier berganda.

Hasil Penelitian menunjukkan bahwa Kepemimpinan, lingkungan kerja non fisik, kompensasi dan motivasi kerja berpengaruh secara simultan terhadap kinerja pegawai Puskesmas Kedungbanteng Kabupaten Tegal yaitu sebesar 84,4\% sedangkan sisanya sebesar 15,6\% dipengaruhi oleh variabel lain di luar penelitian ini seperti kesesuaian kerja, penghargaan, lingkungan kerja fisik dan pendelegasian kerja. Saran bagi pihak pimpinan puskesmas Kedungbanteng Kabupaten Tegal, bahwa dalam rangka meningkatkan kinerja pegawai maka harus menekankan pada motivasi kerja, kepemimpinan dan menciptakan lingkungan kerja yang kondusif.
\end{abstract}

Kata Kunci: kepemimpinan, lingkungan kerja non fisik, kompensasi, motivasi kerja, kinerja Pegawai

\section{Pendahuluan}

Puskesmas sebagai ujung tombak pelayanan kesehatan merupakan penunjang keberhasilan pelaksanaan program kesehatan nasional di Indonesia. Puskesmas berada pada tingkat dasar dalam organisasi kesehatan dimana tenaga kesehatan bekerja sama untuk mencapai tujuan pembangunan kesehatan. Keberhasilan pencapaian Rencana Strategis Kementerian Kesehatan Republik Indonesia akan sangat dipengaruhi oleh penataan dan pengelolaan tenaga dalam melaksanakan kegiatan pokok puskesmas (Sulaeman, 2009).

Kinerja tenaga kesehatan meliputi dokter, perawat, bidan, gizi, farmasi, serta komponen lainnya yang berada di lingkungan puskesmas sangat penting untuk mewujudkan pelayanan yang berkualitas sesuai dengan tujuan Kementerian Kesehatan Republik Indonesia. Puskesmas membutuhkan pegawai yang bersemangat serta tim kerja yang terarah dan ISSN: $2337778 \mathrm{X}$ terpadu untuk menghasilkan prestasi kerja terbaik (Depkes RI, 2010).

Faktor yang mempengaruhi kinerja diantaranya faktor kepemimpinan, faktor pribadi meliputi motivasi, disiplin, kepemimpinan dan keterampilan, faktor sistem dan faktor situasional atau lingkungan kerja. Lingkungan dan iklim kerja yang baik akan mendorong pegawai agar senang bekerja dan puas dengan pekerjaannya, sehingga meningkatkan rasa tanggung jawab untuk melakukan pekerjaan dengan lebih baik menuju ke arah peningkatan kinerja (Sedarmayanti, 2011).

Menurut Rivai (2011) kepemimpinan adalah sebagai proses mengarahkan dan memengaruhi aktivitas-aktivitas yang ada hubungannya dengan pekerjaan para anggota kelompok. Kemampuan mempengaruhi akan menentukan cara yang digunakan bawahan dalam mencapai hasil kerja. Gaya kepemimpinan seorang pemimpin dapat mempengaruhi kinerja. 


\section{Jurnal Magisma Vol. 6 No. 1 - Tahun $2018 \mid 36$}

Dalam organisasi publik, bawahan bekerja selalu tergantung pada pimpinan. Bila pimpinan tidak memiliki kemampuan memimpin, maka tugastugas yang sangat kompleks tidak dapat dikerjakan dengan baik.

Menurut Sedarmayanti (2011) faktor-faktor yang mempengaruhi kinerja antara lain sikap mental, pendidikan, keterampilan, kepemimpinan, tingkat penghasilan, kompensasi, komunikasi, sarana pra sarana, kesempatan berprestasi. Komunikasi salah satu hal yang berpengaruh terhadap kinerja pegawai. Komunikasi berhubungan erat dengan ligkungan kerja pegawai. Menurut Onong (2011), interaksi pegawai dan pimpinan dalam lingkungan perusahaan merupakan hal yang tidak dapat dipisahkan yang mana akan menimbulkan perasaan senang dan semangat kerja pegawai, situasi lingkungan perusahaan dalam melaksanakan tugas dan fungsinya antara pegawai yang satu dengan yang lain tidak terlepas dari interaksi satu sama lainnya demi kelancaran dan keharmonisan kerja. Sarana hubungan yang nyaman komunikasi yang baik akan lebih betah dan senang dalam menyelesaikan tugas. Dengan demikian yang terpenting dalam mewujudkan human relation adalah bagaimana kita memahami hakekat manusia serta bagaimana kita mampu menerima orang lain di luar diri kita dengan apa adanya serta mampu bersikap yang profesional dalam bekerja agar tercipta suasana kerja yang harmonis, menyenangkan dan baik yang kemudian meningkatkan semangat kerja yang akan mempengaruhi juga hasil pekerjaan.

Faktor kompensasi juga mempengaruhi kinerja pegawai, karena kompensasi merupakan suatu bentuk balas jasa yang diberikan organisasi kepada para pegawainya yang dapat dinilai dengan uang dan memiliki kecenderungan diberikan secara tetap dengan harapan organisasi akan memperoleh imbalan dalam bentuk prestasi kerja pegawainya. Selain gaji, pegawai Puskesmas akan mendapatkan kompensasi dapat berupa jasa pelayanan (jaspel). Sistem pembagian jaspel JKN diatur dengan Permenkes Nomor 19 tahun 2014 yang disempurnakan dengan Permenkes Nomor 28 tahun 2014. Pembagian jaspel JKN ditetapkan dengan menggunakan variable jenis ketenagaan dan/atau jabatan serta kehadiran. Pemerintah daerah dalam hal ini dinas kesehatan dapat menambah variable lain seperti kinerja, status kepegawaian dan masa kerja sesuai dengan kondisi daerah (Kemenkes, 2014).

Motivasi merupakan daya penggerak dari dalam untuk melakukan kegiatan untuk mencapai tujuan (Sardiman 2006). Menurut Sardiman (2006) motivasi merupakan perubahan energi dalam diri seseorang yang ditandai dengan munculnya feeling dan didahului dengan tanggapan terhadap adanya tujuan. Berdasarkan atas penelitian yang dilakukan Sutisna (2008), antara motivasi kerja dengan kinerja kerja pegawai mempunyai hubungan yang nyata, ini ditandakan dengan nilai peluang (sig.) pengujian sebesar 0,003 yang lebih kecil dari 0,05. Semakin baik motivasi kerja pegawai maka akan semakin baik kinerjanya. Pegawai dengan karakteristik individu, karakteristik pekerjaan dan karakteristik situasi kerja yang tinggi dalam pekerjaannya maka dalam dirinya cenderung akan mempunyai kinerja yang tinggi atau mempunya sifat kerja keras, kerja cerdas dan kerja ikhlas.

Hasil pengamatan pra penelitian berupa wawancara dengan salah seorang penanggung jawab program di Dinas Kesehatan Kabupaten Tegal menyatakan bahwa dalam pelaksanaan tugas banyak pegawai puskesmas yang hanya menunggu pasien datang ke puskesmas. Padahal terdapat beberapa tugas yang mengharuskan pegawai puskesmas mendatangi rumah penduduk untuk mendapatkan pelayanan kesehatan. Kondisi ini dilatarbelakangi oleh banyaknya keluhan petugas puskesmas, terkait imbalan yang mereka peroleh tidak sebanding dengan tugas yang dilaksanakan. Wawancara juga dilakukan dengan salah seorang pimpinan puskesmas di Kabupaten Tegal. Informasi yang diperoleh dari wawancara tersebut adalah puskesmas mengupayakan agar setiap kegiatan terlaksana sesuai jadwal, namun seringkali pelaksanaan beberapa kegiatan menjadi tertunda akibat pegawai yang tidak disiplin. Pegawai puskemas sering terlambat masuk kerja atau tidak hadir tanpa alasan dan pulang sebelum jam pulang kerja.

Puskesmas Kedungbanteng adalah salah satu Puskesmas di Kabupaten Tegal, berdasarkan 


\section{Jurnal Magisma Vol. 6 No. 1 - Tahun 2018}

dari laporan tahunan Dinas Kesehatan Kabupaten Tegal Puskesmas Kedungbanteng pada tahun 2016 cakupan hasil kinerja puskesmas sebesar 92,1\% atau menurun dibandingkan dengan tahun 2015 sebasar 93,85\%. Pencapaian program kesehatan Puskesmas Kedungbanteng pada tahun 2016 sebagian besar belum memenuhi target pencapaian yang ditentukan oleh Dinas Kesehatan Kabupaten Tegal kecuali program upaya kesehatan pengembangan (93\%) dan upaya P3M (114\%) sudah memenuhi target.

Kinerja pegawai puskesmas Kedungbanteng mengalami penurunan. Hal ini ditandai dengan banyaknya program Puskesmas yang tidak mencapai target. Penyebabnya yaitu banyaknya tugas dan tanggung jawab yang diberikan kepada pegawai puskesmas. Sehingga hasil yang dicapai menjadi kurang maksimal, karena Pegawai puskesmas hanya mempunyai waktu yang sedikit untuk menyelesaikan banyak tugas. Selain itu banyaknya masyarakat yang mengeluh dan rendahnya tingkat kepuasan pasien terhadap pelayanan yang diberikan.

Hal ini dapat dilihat dari nilai Indeks Kepuasan Pasien (IKP) Puskesmas Kedungbanteng tahun 2016 yaitu sebesar $77,45 \%$. Keluhan dari masyarakat terhadap pelayanan yang diberikan oleh pegawai puskesmas yaitu adanya lama waktu tunggu di loket antrian karena pegawai yang bertugas terlambat datang, kurangnya edukasi pegawai terhadap masyarakat dan tidak ada kesempatan untuk menanyakan lebih lanjut/lebih dalam mengenai penyakit yang diderita karena pegawai puskesmas harus menangani banyaknya masyarakat yang berkunjung. Sehingga hal tersebut dapat mempengaruhi mutu pelayanan Puskesmas dan akan berdampak pada kinerja Pegawai puskesmas Kedungbanteng.

Hasil pengamatan pra penelitian berupa wawancara dengan salah seorang penanggung jawab program di Dinas Kesehatan Kabupaten Tegal menyatakan bahwa dalam pelaksanaan tugas banyak pegawai puskesmas yang hanya menunggu pasien datang ke puskesmas. Padahal terdapat beberapa tugas yang mengharuskan pegawai puskesmas mendatangi rumah penduduk untuk mendapatkan pelayanan kesehatan. Kondisi ini dilatarbelakangi oleh banyaknya keluhan petugas puskesmas, terkait imbalan yang mereka peroleh tidak sebanding dengan tugas yang dilaksanakan. Wawancara juga dilakukan dengan salah seorang pimpinan puskesmas Kedungbanteng. Informasi yang diperoleh dari wawancara tersebut adalah puskesmas mengupayakan agar setiap kegiatan terlaksana sesuai jadwal, namun seringkali pelaksanaan beberapa kegiatan menjadi tertunda akibat pegawai yang tidak disiplin. Pegawai puskemas sering terlambat masuk kerja atau tidak hadir tanpa alasan dan pulang sebelum jam pulang kerja.

Penelitian yang dilakukan Setiari (2013), Muslim (2016), dan Handayani (2017) menunjukan bahwa kepemimpinan mempengaruhi Kinerja pegawai Puskesmas, begitu juga lingkungan kerja berpengaruh terhadap kinerja pegawai puskesmas (Qurtuby, 2017), (Muslim, 2016), juga kompensasi mempunyai pengaruh terhadap kinerja pegawai Puskesmas Totikum, Kab. Banggai Kepulauan, Sulawesi Tengah (Handayani, 2017). Dari penelitian ini juga diperoleh nilai Adjusted $R$ Square sebesar 0,741, hal tersebut berarti bahwa $74,1 \%$ variabel kinerja pegawai dapat dijelaskan oleh variabel independennya, yaitu kepemimpinan, lingkungan kerja, dan kompensasi serta motivasi kerja sedangkan sisanya sebesar $25,9 \%$ dijelaskan oleh variabelvariabel lain di luar penelitian.

Penelitian ini bertujuan untuk memperoleh bukti empiris mengenai pengaruh pengaruh kepemimpinan, lingkungan kerja non fisik, kompensasi dan motivasi kerja terhadap kinerja Pegawai Puskesmas Kedungbanteng Kabupaten Tegal.

\section{Metode Penelitian}

Jenis penelitian penjelasan (explanatory research) karena bermaksud menjelaskan hubungan kausal antara variabel-variabel melalui pengujian hipotesis. Sumber data yang digunakan dalam penelitian ini meliputi data primer, yaitu data yang diperoleh dari responden melalui kuesioner yang telah dibuat sesuai dengan indikator penelitian dan juga berdasarka data sekunder. Populasi dari penelitian ini adalah seluruh Pegawai di Puskesmas Kedungbanteng Kabupaten Tegal yang berjumlah 48 orang. Teknik pengambilan sampel dengan 


\section{Jurnal Magisma Vol. 6 No. 1 - Tahun 2018}

menggunakan metode total sampling yaitu teknik sampling yang dilakukan dengan mengambil semua jumlah populasi.

Metode pengumpulan data yang digunakan dalam penelitian ini adalah menggunakan kuisioner. Skala yang digunakan untuk mengukur indikator-indikator variabel dalam kuisioner adalah Skala Likert. Analisis data menggunakan regresi linier berganda setelah terlebih dahulu dilakukan uji asumsi klasik dan uji kelayakan model.

\section{Hasil dan Pembahasan \\ Uji Validitas Validitas}

Uji validitas menggunakan koefisien korelasi Product Momen Pearson. Butir kuesioner dinyatakan sahih atau valid, jika $R_{\text {hitung }}$ $>\mathrm{R}_{\text {tabel}}$, uji validitas dilakukan pada 48 responden di luar responden penelitian, sehingga didapatkan $\mathrm{R}_{\text {tabel }}$ adalah 0,284. Hasil uji validitas kuesioner tentang kepemimpinan (X1), lingkungan kerja non fisik (X2), kompensasi (X3), motivasi kerja (X4) dan kinerja pegawai (Y) dinyatakan valid karena $R_{\text {hitung }}$ masingmasing butir kuesioner diatas nilai $\mathrm{R}_{\text {Tabel }}, 0,284$.

\section{Reliabilitas}

\section{Tabel 1 Reliabilitas}

\begin{tabular}{|l|c|}
\hline Variabel & Alpha \\
\hline Kepemimpinan & 0,902 \\
\hline Lingkungan Kerja non fisik & 0,749 \\
\hline Kompensasi & 0,838 \\
\hline Motivasi Keria & 0,812 \\
\hline Kinerja & 0,855 \\
\hline
\end{tabular}

Dari keempat variabel nilai $r$ alpha yang dihasilkan bernilai positif dan lebih besar dari 0,06 . Hasil keseluruhan instrumen penelitian ini handal.

\section{Pengujian Persyaratan Analisis}

1) Uji Normalitas

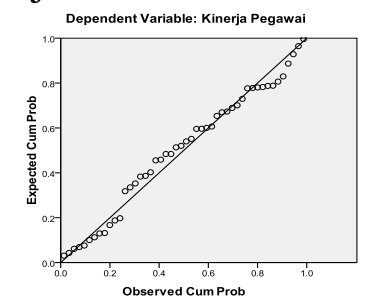

Berdasarkan gambar di atas dapat diketahui bahwa penyebaran data (titik) pada Normal PPlot of Regression Standardized dari variabel terikat menyebar di sekitar garis diagonal, maka model regresi memenuhi asumsi normalitas.
2) Uji Multikoliniaritas Tabel 2 Hasil Uji Multikolinier

\begin{tabular}{|ll|r|c|}
\hline \multirow{2}{*}{ Model } & & \multicolumn{2}{|c|}{ Collinearity Statistics } \\
\cline { 2 - 3 } & & Tolerance & VIF \\
\hline 1 & (Constant) & & \\
& Kepemimpinan & .452 & 2.215 \\
& Lingkungan Kerja non fisik & .527 & 1.896 \\
& Kompensasi & .536 & 1.865 \\
& Motivasi Kerja & .404 & 2.475 \\
\hline
\end{tabular}

Hasil uji multikolinearitas pada pada tabel di atas diketahui bahwa hasil tolerance pada masing-masing variabel lebih besar dari 0,1 , sedangkan nilai Varians Inflation Factor (VIF) lebih kecil dari 10. Sehingga model regresi dalam penelitian ini tidak ada masalah multikolinearitas.

3) Uji Heteroskedastisitas

Scatterplot

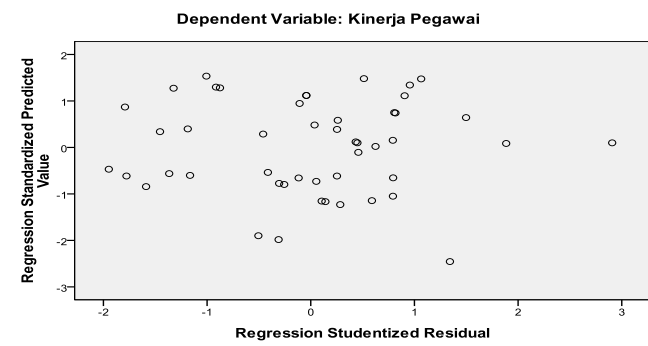

Gambar di atas tidak menunjukkan adanya pola tertentu yang berarti tidak terjadi heterokodesitas dalam model regresi.

\section{Pengujian Hipotesis} Uji F

Tabel 3 Uji F
ANOVA
\begin{tabular}{|l|l|r|r|r|r|c|}
\hline \multicolumn{1}{c|}{} \\
\hline \multirow{2}{*}{ Model } & $\begin{array}{l}\text { Sum of } \\
\text { Squares }\end{array}$ & Df & $\begin{array}{c}\text { Mean } \\
\text { Square }\end{array}$ & F & Sig. \\
\hline \multirow{2}{*}{1} & Regression & 1166.059 & 4 & 291.515 & 58.055 & $.000^{\mathrm{a}}$ \\
\cline { 2 - 8 } & Residual & 215.920 & 43 & 5.021 & & \\
\cline { 2 - 8 } & Total & 1381.979 & 47 & & & \\
\hline
\end{tabular}

a. Predictors: (Constant), Motivasi Kerja, Lingkungan Kerja non fisik, Kompensasi, Kepemimpinan

b. Dependent Variable: Kinerja Pegawai

Berdasarkan tabel di atas dapat diperoleh nilai sig. $(0,000)<0,05$ yang berarti bahwa diketahui bahwa Kepemimpinan, lingkungan kerja non fisik, kompensasi dan motivasi kerja berpengaruh secara simultan terhadap kinerja 


\section{Jurnal Magisma Vol. 6 No. 1 - Tahun 2018}

pegawai Puskesmas Kedungbanteng Kabupaten Tegal.

\section{Koefisien Determinasi $\left(\mathbf{R}^{2}\right)$}

Adapun Untuk mengukur sumbangan variabel bebas terhadap variabel terikat dapat diketahui besarnya koefisien determinasi ganda $\left(\mathrm{R}^{2}\right)$, hasilnya sebagai berikut:

Tabel 4 Koefisien Determinasi Model Summary ${ }^{\mathrm{D}}$

\begin{tabular}{|l|c|r|r|r|}
\hline Model & $\mathrm{R}$ & $\begin{array}{c}\mathrm{R} \\
\text { Square }\end{array}$ & $\begin{array}{c}\text { Adjusted } \mathrm{R} \\
\text { Square }\end{array}$ & $\begin{array}{c}\text { Std. Error of the } \\
\text { Estimate }\end{array}$ \\
\hline 1 & $.919^{\mathrm{a}}$ & .844 & .829 & 2.24085 \\
\hline
\end{tabular}

a. Predictors: (Constant), Motivasi Kerja, Lingkungan Kerja non fisik, Kompensasi, Kepemimpinan

b. Dependent Variable: Kinerja Pegawai

Berdasarkan analisis koefisien determinasi untuk persamaan regresi diperoleh koefisien determinasi (Adjusted $\mathrm{R}^{2}$ ). Penggunaan Adjusted $\mathrm{R}^{2}$ dikarenakan tidak mengandung bias terhadap jumlah variabel yang digunakan sebagaimana jika menggunakan $\mathrm{R}^{2}$ (Ghozali, 2005). Nilainya sebesar 0,844, artinya pengaruh variabel kepemimpinan, lingkungan kerja, kompensasi dan motivasi kerja secara bersama-sama terhadap kinerja pegawai Puskesmas Kedungbanteng Kabupaten Tegal (Y) sebesar 84,4\% sedangkan sisanya sebesar $15,6 \%$ dipengaruhi oleh variabel lain di luar penelitian ini.

\section{Regreis Berganda}

\section{Tabel 5 Uji t}

Coefficients $^{\mathrm{a}}$

\begin{tabular}{|c|c|c|c|c|c|}
\hline \multirow[b]{2}{*}{ Model } & \multicolumn{2}{|c|}{$\begin{array}{c}\text { Unstandardized } \\
\text { Coefficients }\end{array}$} & \multirow{2}{*}{$\begin{array}{c}\begin{array}{c}\text { Standardize } \\
\mathrm{d} \\
\text { Coefficients }\end{array} \\
\text { Beta }\end{array}$} & \multirow[b]{2}{*}{$t$} & \multirow[b]{2}{*}{ Sig. } \\
\hline & B & Std. Error & & & \\
\hline $1 \quad$ (Constant) & -2.968 & 3.036 & & -.978 & .334 \\
\hline Kepemimpinan & .206 & .057 & .326 & 3.638 & .001 \\
\hline Lingkungan Kerja & .201 & .093 & .179 & 2.154 & .037 \\
\hline Non Fisik & & & & & \\
\hline Kompensasi & .082 & .061 & .111 & 1.346 & .186 \\
\hline Motivasi Kerja & .463 & .097 & .454 & 4.792 & .000 \\
\hline
\end{tabular}

a. Dependent Variable: Keberhasilan Peran Konsulting

Analisis Berdasarkan hasil penelitian diatas maka diperoleh hasil sebagai berikut: $\mathrm{Y}=-2,968+0,206 \cdot \mathrm{X} 1+0,201 \cdot \mathrm{X} 2+0,082 \cdot \mathrm{X} 3+0,463 \cdot \mathrm{X} 4+\mathrm{e}$
dengan
$\mathrm{Y}=$ Kinerja Pegawai

$\mathrm{X} 1$ = Kepemimpinan

$\mathrm{X} 2$ = Lingkungan kerja non fisik

$\mathrm{X} 3=$ Kompensasi

X4 = Motivasi kerja

Dari hasil estimasi regresi yang diperoleh dapat dijelaskan makna koefisien regresi sebagai berikut :

$\mathrm{a}=-2,968 \quad$ Menunjukkan nilai konstanta dari Kinerja Pegawai, yang berarti jika pengaruh Kepemimpinan, Lingkungan kerja non fisik, kompensasi dan motivasi kerja sama dengan nol maka nilai Kinerja Pegawai Puskesmas Kedungbanteng adalah sebesar 2,968.

b1 $=0,206$ Artinya apabila variabel Kepemimpinan naik $1 \%$ maka Kinerja Pegawai Puskesmas Kedungbanteng akan naik sebesar 0,206 kali. Variabel Kepemimpinan berpengaruh positip terhadap Kinerja Pegawai Puskesmas Kedungbanteng.

b2 $=0,201 \quad$ Artinya apabila variabel lingkungan kerja non fisik naik 1 $\%$ maka Kinerja Pegawai Puskesmas Kedungbanteng akan naik sebesar 0,201 kali. Variabel lingkungan kerja non fisik berpengaruh positif terhadap Kinerja Pegawai.

b3 $=0,082$ Artinya apabila variabel kompensasi naik $1 \%$ maka Kinerja Pegawai akan naik sebesar 0,082 kali. Variabel Kompensasi berpengaruh positif terhadap kinerja Pegawai Puskesmas Kedungbanteng artinya kompensasi yang diberikan kepada pegawai mempengaruhi kinerja pegawai.

B4 $=0,463$ Artinya apabila variabel motivasi kerja naik 1 maka Kinerja Pegawai akan naik sebesar 0,463 kali. Variabel motivasi kerja berpengaruh positif terhadap Kinerja Pegawai Puskesmas Kedungbanteng. 


\section{Jurnal Magisma Vol. 6 No. 1 - Tahun 2018 $\mid 40$}

Berdasarkan besarnya koefisien beta, maka pengaruh paling dominan variabel bebas terhadap variabel terikat adalah pengaruh variabel motivasi kerja karena koefisien betanya (Standardized Coefficients) paling besar dibandingkan lainnya yaitu 0,454 .

\section{Uji t}

Pengujian selanjutnya dilakukan untuk menguji hipotesis secara parsial dengan uji $t$ berdasarkan pada tabel 4.23

H.1. Kepemimpinan berpengaruh positif terhadap kinerja pegawai Puskesmas Kedungbanteng Kabupaten Tegal.

H.2 Lingkungan kerja non fisik berpengaruh positif terhadap kinerja pegawai Puskesmas Kedungbanteng Kabupaten Tegal.

H.3 Kompensasi berpengaruh positif terhadap kinerja pegawai Puskesmas Kedungbanteng Kabupaten Tegal.

H.4 Motivasi kerja berpengaruh positif terhadap kinerja pegawai Puskesmas Kedungbanteng Kabupaten Tegal.

Kriteria pengujian

Sig t hitung $<0,05$, maka Hipotesis diterima

Sig t hitung $>0,05$, maka Hipotesis ditolak

Pengambilan keputusan :

Dari hasil perhitungan diperoleh hasil sebagai berikut:

1) Kepemimpinan berpengaruh positif terhadap kinerja pegawai Puskesmas Kedungbanteng Kabupaten Tegal. Hal ini ditunjukkan oleh nilai sig t hitung $(0,001)<0,05$.

2) Lingkungan kerja non fisik berpengaruh positif terhadap kinerja pegawai Puskesmas Kedungbanteng Kabupaten Tegal. Hal ini ditunjukkan oleh nilai sig t hitung $(0,037)<$ 0,05 .

3) Kompensasi tidak berpengaruh terhadap kinerja pegawai Puskesmas Kedungbanteng Kabupaten Tegal. Hal ini ditunjukkan oleh nilai sig t hitung $(0,186)>0,05$.

4) Motivasi kerja berpengaruh positif terhadap kinerja pegawai Puskesmas Kedungbanteng Kabupaten Tegal. Hal ini ditunjukkan oleh nilai sig t hitung $(0,000)<0,05$.

\section{PEMBAHASAN}

Pengaruh Kepemimpinan terhadap kinerja pegawai Puskesmas Kedungbanteng Kabupaten Tegal

Hasil penelitian menunjukkan bahwa Kepemimpinan berpengaruh positif terhadap kinerja pegawai Puskesmas Kedungbanteng Kabupaten Tegal. Hal ini ditunjukkan oleh nilai sig t hitung $(0,001)<0,05$, artinya semakin positif atau tinggi kepemimpinan pegawai akan semakin tinggi kinerja pegawai, hasil penelitian menunjukkan bahwa sebagian besar kepemimpinan dalam kategori tinggi dan kinerja pegawai juga dalam kategori tinggi $(29,2 \%)$, ini menunjukkan bahwa pegawai sudah memiliki kompetensi yang bagus, karena kemampuan dan karakteristik yang dimiliki oleh seorang pegawai, berupa pengetahuan, ketrampilan, dan sikap perilaku yang diperlukan pada tugas jabatannya, sehingga pegawai tersebut dapat melaksanakan tugasnya secara professional, efektif dan efisien.

Berdasarkan hasil penelitian menunjukkan bahwa kepemimpinan di Puskesmas Kedungbanteng masih kurang dalam mengarahkan pegawai puskesmas, kurang memberi inspirasi kepada anak buah untuk melakukan sesuatu melebihi tugas yang wajib, akan tetapi kepemimpinan di Puskesmas Kedungbanteng sudah bagu dalam hal atasan mampu mendorong bawahannya untuk lebih kreatif dalam bekerja, kepala Puskesmas mempunyai ekspektasi yang tinggi dalam pekerjaan, senantiasa mempertimbangkan kebutuhan dari bawahannya, suka memberikan pelatihan dan memberikan saran kepada bawahannya, sehingga berdampak pada kinerja pegawai puskesmas.

Hal ini sejalan dengan pendapat Wibowo (2007) mengemukakan bahwa suatu kemampuan untuk melaksanakan atau melakukan suatu pekerjaan atau tugas yang dilandasi atas keterampilan dan pengetahuan serta didukung oleh sikap kerja yang dituntut oleh pekerjaan itu tersebut. Hasil penelitian ini juga, seperti penelitian yang dilakukan oleh June dan Mahmood (2011), The Relationship between Role Ambiguity, Competency and Person-Job Fit With the Job Performance of Employees in the Service Sector SMEs in Malaysia yang 


\section{Jurnal Magisma Vol. 6 No. 1 - Tahun $2018 \mid 41$}

menyatakan bahwa kepemimpinan berpengaruh secara positif dan signifikan terhadap kinerja.

\section{Pengaruh Lingkungan kerja non fisik terhadap kinerja pegawai Puskesmas Kedungbanteng Kabupaten Tegal}

Berdasarkan hasil penelitian diketahui bahwa lingkungan kerja non fisik berpengaruh positif terhadap kinerja pegawai Puskesmas Kedungbanteng Kabupaten Tegal. Hal ini ditunjukkan oleh nilai sig t hitung $(0,037)<0,05$, yang berarti bahwa semakin tinggi lingkungan kerja non fisik maka akan berdampak semakin tinggi kinerja pegawai, begitu juga sebaliknya. Hal ini karena lingkungan kerja merupakan segala sesuatu di sekitar pegawai dan dapat berpengaruh terhadap pekerjanya. Dengan lingkungan kerja yang nyaman membuat pegawai untuk bekerja lebih baik sehingga kinerja yang dicapai dapat maksimal

Kondisi lingkungan kerja non fisik di Puskesmas Kedungbanteng sudah cukup baik dalam kategori tinggi, dimana hubungan sesama pegawai, hubungan dengan atasan, hubungan dengan masyarakat atau pasien terjadi baik yang dapat menimbulkan suatu sikap, pendapat atau perilaku yang saling pengertian didalam melaksanakan pekerjaan, setiap pegawai mampu memberikan informasi yang mudah dimengerti pada klien. Hal ini berpengaruh kepada kinerja pegawai puskesmas Kedungbanteng yang mampu mematuhi norma-norma yang berlaku pada instansi tempat bekerja dan dalam melakukan kewajiaban siap meletakkan jabatan jika tidak sesuai target.

Lingkungan kerja non fisik yang menyenangkan bagi pegawai melalui pengikatan hubungan yang harmonis dengan atasan maupun bawahan, serta didukung oleh sarana dan prasarana memadai yang ada di tempat bekerja akan membawa dampak positif bagi pegawai sehingga kinerja meningkat. Hasil penelitian dilakukan oleh Hardiyana, Helwiyan (2011) diketahui Variabel lingkungan kerja berpengaruh terhadap kinerja pegawai adalah sebesar 0.169 atau $16.9 \%$. Penelitian yang diakukan oleh Arifah (2015) menunjukkan bahwa indeks jawaban responden menunjukkan bahwa variabel Kondisi Lingkungan kerja non fisik mempunyai nilai indeks sebesar 81,15 yang merupakan tingkatan skor tinggi. Variabel lingkungan kerja non fisik memiliki pengaruh positif dan signifikan terhadap kinerja pegawai (Y) dengan nilai regresi 0,816 dan nilai t hitung $=5,234$ dengan tingkat signifikansi 0,000.

\section{Ada pengaruh yang signifikan antara Kompensasi terhadap kinerja pegawai}

Hasil penelitian menunjukkan bahwa kompensasi tidak berpengaruh posisitf terhadap kinerja pegawai Puskesmas Kedungbanteng Kabupaten Tegal Hal ini ditunjukkan oleh nilai sig $\mathrm{t}$ hitung $(0,186)>0,05$, sebagai tenaga kesehatan akan melakukan pekerjaan yang berhubungan dengan keselamatan masyarakat dalam meningkatkan derajat kesehatan sehingga mempunai komitmen yang tinggi dalam bekerja, hal ini menunjukkan bahwa ada atau tidak adanya kompensasi, besar atau kecil kompensasi tidak berpengaruh pada pekerjaan pegawai.

Pegawai Puskesmas Kedungbanteng Kabupaten Tegal sebagian besar memiliki kompensasi yang tinggi $(35,4 \%)$ artinya kompensasi yang didapat pegawai puskesmas dengan pembagian jaspel dilakukan seperti pembagian jaspel umum maupun jaspel JKBM (Jaminan Kesehatan Bali Mandara) karena perhitungannya berdasarkan kesepakatan bersama. Pada 1 Januari 2017 peserta JKBM ditargetkan sudah terintegrasi dengan JKN dan tahun 2019 seluruh masyarakat wajib menjadi peserta JKN sehingga semua otomatis akan mengikuti pembagian jaspel berdasarkan aturan JKN. Kondisi di atas tidak menjadi pengaruh terhadap kinerja pegawai, hal ini karena sejak sebelum digulirkan jaspel ini pegawai puskesmas sudah terbiasa melakukan pekerjaannya dengan baik.

Hasil penelitian ini tidak sesuai dengan teori hubungan antara kompensasi dengan kinerja, Syarifudin (2005) melakukan kajian tentang analisis faktor-faktor yang mempengaruhi kinerja pegawai dengan kesimpulan bahwa kesesuaian penghasilan berpengaruh positif terhadap kinerja. Hal ini karena sebagian besar pegawai Puskesmas Kedungbanteng adalah Pegawai Negeri Sipil.

Dan tidak sesuai dengan penelitian yang dilakukan oleh Christie (2012) menemukan bahwa pengetahuan pegawai tentang struktur gaji 


\section{Jurnal Magisma Vol. 6 No. 1 - Tahun $2018 \mid 42$}

dan kebijakan perusahaan mengenai kompensasi dapat langsung berhubungan dengan kinerja. Penelitian lain yang dilakukan oleh Carlson et al. (2016) juga menemukan pemberian kompensasi tunai yang kompetitif dapat memberikan dampak yang positif bagi performa perusahaan.

\section{Pengaruh Motivasi kerja terhadap kinerja pegawai}

Melalui pengujian hipotesis, motivasi terbukti membawa pengaruh yang positif terhadap kinerja pegawai Puskesmas Kedungbanteng Kabupaten Tegal. Koefisien pengaruh variabel motivasi adalah sebesar 0,454 dan sig $=0.000<0,005$. Hal ini menunjukkan bahwa semakin tinggi motivasi pegawai maka kinerja pegawai semakin baik, dengan adanya motivasi tinggi, seorang pegawai akan merasa mempunyai dorongan khusus untuk menyelesaikan suatu pekerjaan menuju tercapainya efektivitas organisasi. Ketika seorang pegawai memiliki motivasi untuk berprestasi, seseorang akan melaksanakan tugas dengan sebaik-baiknya, namun ketika orang menganggap bahwa melaksanakan pekerjaan hanya sebagai suatu rutinitas maka mereka cenderung statis dalam bekerja.

Berdasarkan hasil penelitian menunjukkan bahwa pegawai puskesmas mempunyai keinginan atau motivasi yang tinggi tentang pekerjaan yang dilakukan sesuai dengan tugas pokok dan fungsinya berdasarkan faktor dari dirinya sendiri maupun dari luar sehingga berdampak pada pegawai puskesmas berusaha keras untuk mencapai prestasi (target) dan ingin mengetahui seberapa baik bekerja dan ketika bekerja fokus pada pekerjaan, hal ini berdampak pada pekerjaan pegawai yang tinggi.

Hasil penelitian ini sesuai dengan penelitian yang dilakukan oleh Sutisna (2008) menunjukkan bahwa antara motivasi kerja dengan kinerja karyawan mempunyai hubungan yang nyata, ini ditandakan dengan nilai peluang (sig.) pengujian sebesar 0,003 yang lebih kecil dari 0,05. Bentuk hubungannya agak lemah dengan nilai korelasi (r) sebesar 0,398. Semakin baik motivasi kerja karyawan maka akan semakin baik kinerjanya. Karyawan dengan karakteristik individu, karakteristik pekerjaan dan karakteristik situasi kerja yang tinggi dalam pekerjaannya maka dalam dirinya cenderung akan mempunyai kinerja yang tinggi.

\section{Kesimpulan}

Berdasarkan hasil penelitian dan pembahasan yang telah dilakukan, maka kesimpulan yang dapat diambil adalah sebagai berikut 1) Kepemimpinan berpengaruh positif terhadap kinerja pegawai Puskesmas Kedungbanteng Kabupaten Tegal (p-value $0,001<0,05)$. 2) Lingkungan kerja non fisik berpengaruh positif terhadap kinerja pegawai Puskesmas Kedungbanteng Kabupaten Tegal (pvalue $0,037<0,05)$. 3) Kompensasi tidak berpengaruh positif terhadap kinerja pegawai Puskesmas Kedungbanteng Kabupaten Tegal (pvalue $0,186>0,05)$. 4) Motivasi kerja berpengaruh positif terhadap kinerja pegawai Puskesmas Kedungbanteng Kabupaten Tegal (pvalue $\quad 0,000<0,05)$. 5) Kepemimpinan, lingkungan kerja non fisik, kompensasi dan motivasi kerja berpengaruh secara simultan terhadap kinerja pegawai Puskesmas Kedungbanteng Kabupaten Tegal, yaitu sebesar $84,4 \%$ sedangkan sisanya sebesar $15,6 \%$ dipengaruhi oleh variabel lain di luar penelitian ini seperti kesesuaian kerja, penghargaan, lingkungan kerja fisik dan pendelegasian kerja.

\section{Saran}

Penelitian ini diharapkan dapat memberikan berbagai manfaat bagi pimpinan puskesmas Kedungbanteng Kabupaten Tegal, bahwa dalam rangka meningkatkan kinerja pegawai maka harus menekankan pada motivasi kerja, kepemimpinan dan menciptakan lingkungan kerja yang kondusif yaitu dengan menjalin komunikasi yang baik dan sambung rasa antara pimpinan dan pegawai

\section{DAFTAR PUSTAKA}

Arifah. 2015. Pengaruh Human Relations Terhadap Kinerja Pegawai Di Kantor Wilayah Kementerian Agama Provinsi Sulawesi Tengah. e-Jurnal Katalogis, Volume 3 Nomor 2, Pebruari $2015 \mathrm{hlm}$ 125-134 


\section{Jurnal Magisma Vol. 6 No. 1 - Tahun $2018 \mid 43$}

Armstrong dan Baron, 1998. Seri Manajemen Sumber Daya Manusia Kepemimpinan. Jakarta: PT Elex Media

Christie. 2012. Tourism: The International Bussines. New Jersey: Prentice Hall.

Depkes RI, 2010. Manajemen Puskesmas. Jakarta: Depkes RI

Handayani. 2017. Analisis Pengaruh Gaya Kepemimpinan dan Motivasi. Kerja Terhadap Kinerja Pegawai (Studi Kasus Dinas Tenaga Kerja. Provinsi Lampung), Jurnal Ilmiah Adminidtrasi Publik dan Pembangunan,. Vol. 1, No.1

Hasibuan, 2013. Manajemen Sumber Daya Manusia, Edisi Revisi. Bumi Aksara, Jakarta.

Helwiyan. 2011. Perilaku dan Manajemen Organisasi, Erlangga, Jakarta

Kemenkes, 2014. Kementerian Kesehatan RI. Peraturan Menteri Kesehatan Republik Indonesia Nomor 28 tahun 2014 Tentang Pedoman Pelaksanaan Program Jaminan Kesehatan Nasional. Jakarta: Kementerian KesehatanI; 2014.

Mahsun, Mohamad, 2006. Pengukuran Kinerja Sektor Publik. Penerbit BPFE,Yogyakarta

Muslim. 2016. Pengaruh Kepemimpinan, Lingkungan Kerja dan Komunikasi Terhadap Kinerja Pegawai Puskesmas Toboali Bangka Selatan
Qurtuby. 2017. Analisis Pengaruh Kepemimpinan, Lingkungan Kerja, Dan Kompensasi Terhadap Kinerja Pegawai Puskesmas Gemuh I Kabupaten Kendal. Tesis. UMS

Rivai dan Basri, 2011. Performance Appraisal. Jakarta: PT. Rajagrafind

Sardiman 2006. interaksi dan Motivasi. Jakarta : PT. Raja Grafindo Persada

Sedarmayanti. 2011. Tata Kerja dan Produktivitas Kerja. Bandung: CV. Mandar.

Setiari, Lutfia Indah 2013. Pengaruh Kepemimpinan, Komunikasi dan Lingkungan Kerja Terhadap Kinerja Pegawai Di Puskesmas Mlarak Kabupaten Ponorogo. Universitas Muhammadiyah Ponorogo

Sulaeman, 2009. Manajemen Kesehatan Teori dan Praktek di Puskesmas. Yogyakarta : Gajah Mada University Press

Sutisna. 2008. Analisis Hubungan Motivasi Kerja Dengan Etos Kerja Pegawai (Studi Kasus Pegawai Fakultas Pertanian IPB). Bogor: IPB

Syarifudin. 2005. Administrasi Pembiayaan Pendidikan. Bandung: CV. Pustaka.

Wibowo. 2007. Manajemen Kinerja. Jakarta: PT. Raja Grafindo Persada 